\title{
Economic burden of torture for a refugee host country: development of a model and presentation of a country case study
}

This article was published in the following Dove Press journal:

ClinicoEconomics and Outcomes Research

2 April 2014

Number of times this article has been viewed

Emmanuel Kabengele

Mpinga ${ }^{1}, *$

Conrad Frey ${ }^{2, *}$

Philippe Chastonay',*

'Institute of Social and Preventive Medicine, Faculty of Medicine, University of Geneva, Geneva, Switzerland; ${ }^{2}$ Psychiatric Clinic, Obwalden Cantonal Hospital, Sarnen, Switzerland

*These authors contributed equally to this work
Correspondence: Emmanuel Kabengele Mpinga

Institute of Social and Preventive

Medicine, Faculty of Medicine, University of Geneva, IMSP-CMU, Rue Michel

Servet I, I2II Geneva 4, Switzerland

Tel +4I 223790463

Fax +4I 223790452

Email emmanuel.kabengele@unige.ch
Background: Torture is an important social and political problem worldwide that affects millions of people. Many host countries give victims of torture the status of refugee and take care of them as far as basic needs; health care, professional reinsertion, and education. Little is known about the costs of torture. However, this knowledge could serve as an additional argument for the prevention and social mobilization to fight against torture and to provide a powerful basis of advocacy for rehabilitation programs and judiciary claims.

Objectives: Development of a model for estimating the economic costs of torture and applying the model to a specific country.

Methods: The estimation of the possible prevalence of victims of torture was based on a review of the literature. The identification of the socioeconomic factors to be considered was done by analogy with various health problems. The estimation of the loss of the productivity and of the economic burden of disease related to torture was done through the human capital approach and the component technique analysis.

Case study: The model was applied to the situation in Switzerland of estimated torture victims Switzerland is confronted with.

Results: When applied to the case study, the direct costs - such as housing, food, and clothing - represent roughly 130 million Swiss francs (CHF) per year; whereas, health care costs amount to 16 million CHF per year, and the costs related to education of young people to 34 million CHF per year. Indirect costs, namely those costs related to the loss of the productivity of direct survivors of torture, have been estimated to one-third of 1 billion CHF per year. This jumps to $10,073,419,200 \mathrm{CHF}$ in the loss of productivity if one would consider 30 years of loss per survivor.

Conclusion: Our study shows that a rough estimation of the costs related to torture is possible with some prerequisites, such as access to social and economic indicators at the country level.

Keywords: cost of torture, victims, violence, state violence, post-traumatic stress disorder, abuse

\section{Introduction}

Torture is an important and terrible social and political problem. It is a major violation of basic human rights. It affects millions of people around the world. ${ }^{1-4}$ However, regarding torture, some questions are a matter of debate: how do we define it; how do we measure it; and how do we estimate its impact on individuals and communities?

The United Nations' Convention against Torture is commonly used to define torture:

Torture means any act by which severe pain or suffering, whether physical or mental, is intentionally inflicted on a person for such purposes as obtaining from him or a third 
person information or a confession, punishing him for an act he or a third person has committed or is suspected of having committed, or intimidating or coercing him or a third person, or for any reason based on discrimination of any kind, when such pain or suffering is inflicted by or at the instigation of or with the consent or acquiescence of a public official or other person acting in an official capacity. It does not include pain or suffering arising only from, inherent in or incidental to lawful sanctions. ${ }^{5}$

This definition, however, raises some conceptual and operational difficulties: 1) it only considers violence inflicted by state representatives, though such violence can be perpetrated by nonstate actors; 2) it only considers severe suffering and pain without defining it more precisely, neither defining the limits between torture and other degrading and inhuman treatments; and 3) it excludes pain and suffering related to lawful sanctions, thus ignoring that nondemocratic states might adopt laws that allow the use of torture.

Thus, there is some semantic ambiguity ${ }^{6}$ on torture. Yet, its practice is frequent throughout the world, and the situation might even have worsened. In 1973, it was reported from $51 \%$ of United Nations' member states; whereas, in 2003, the proportion was up to $78 \% .^{7-10}$

Most victims of torture present physical as well as psychological sequels, which often leaves them in a fragile situation, both individually and socially. Most victims never get a chance to leave the country of torture; few manage to escape and find refuge in a host country.

Let us keep in mind that in 2010 there was an estimate of 10.5 million United Nations High Commissioner for Refugees-supported refugees worldwide. In addition, $62 \%$ lived in ten host countries (Pakistan, 1.9 million; Iran, 1.1 million; Syria, 1 million; Germany, 594,300; and, further down, USA, 265,000; and Great Britain, 238,000). ${ }^{11}$

Some host countries give victims of torture the status of refugee and take care of them as far as their basic needs, health care, professional reinsertion, and education of children are concerned. This might represent a strain on the host country resources and contribute to the radicalization of migration policies.

Yet few host countries implement a coherent and tough policy condemning torture, nor do they put much pressure on countries where torture is the rule, ${ }^{9,10}$ leaving it to nongovernmental organizations (NGOs) to stand up against torture. ${ }^{12} \mathrm{~A}$ model for estimating the economic burden of torture for a host country might contribute to a change of attitude in this regard, thus ultimately bringing down torture around the world.

Indeed, a better understanding of the economic cost of torture - which corresponds to the financial charges related to health care and the rehabilitation of victims of torture, but also to the financial charges related to their professional reorientation, to the education of their children, and to their basic needs, such as housing and food - is needed. But the economic cost of torture also includes prevention programs targeting torture, such as the education of potential executioners or of society at-large.

A better understanding of the costs related to torture might also raise strong economic arguments in favor of torture prevention programs and bring torture practice down as much as possible. It would also plead in favor of well-structured rehabilitation programs that allow victims and their families to live a normal life. Furthermore, a better understanding may also help to overcome the impunity of torture-practicing countries and to facilitate the development of rehabilitation programs in host countries. ${ }^{13-15}$ It might also initiate fairer reparation of victims of torture. Finally, it could possibly promote - on a larger level - the social mobilization of populations and concrete measures of governments against torture. ${ }^{16}$

We present a model for the estimation of the costs related to torture that a host country of torture victims might face, as well as a case study with data from Switzerland. This has not specifically been done so far, ${ }^{17}$ although there has been work done on the economics of torture, such as the work of Yakovlev. $^{18}$

A recent study, conducted by the African Center for Treatment and Rehabilitation of Torture Victims of Uganda, which estimated the economic costs related to victims of torture in their own country, demonstrates - using the human capital approach - that the "lost gross output is the major element in the overall loss output, regardless of severity of torture and sex of torture survivor". ${ }^{19}$

\section{Methods}

\section{Model conception}

\section{Estimation of prevalence of victims} of torture in a host country (step I)

The estimation of the possible prevalence of victims of torture was based on a review of the literature concerning studies mainly done among refugees seeking asylum in a host country, which prohibits torture. ${ }^{20-23}$ In our case, the number of potential torture survivors has been estimated on the basis of accepted refugees among the asylum seekers 
by the Swiss Confederation, as annually reported by the Federal Office of Migration. ${ }^{24}$ On this population, several economic indicators have been applied, similar to those used to study the economic costs of drug abuse or some chronic diseases. ${ }^{25-30}$

\section{Identification of socioeconomic} indicators to be considered (step 2)

A review of the possible socioeconomic indicators to take into consideration was performed based on the literature investigating various health problems. ${ }^{25-30}$ The considered economic indicators were the mean age of torture survivors, mean wages, the invalidity rate, and mean living expenses. The sociodemographic indicators are based on the profile of torture survivors followed by the ambulatory service for victims of torture and war of the Swiss Red Cross and of the Swiss Federal Office of Statistics.

\section{Estimation of social and economic costs related to torture (step 3)}

The direct costs include the mean daily amount of money the state allocates to the health care costs of asylum seekers. They have been estimated based on the prevalence of torture survivors and their sociodemographic profile.

The indirect costs include the costs related to the loss of productivity and to invalidity. They have been estimated based on the human capital approach, according to which individuals who suffer from a disease or a disability are less productive, more prone to becoming an invalid, and to die early. ${ }^{31-35}$

\section{Model application: Switzerland's situation as a case study}

These described approaches were applied to data from Switzerland $\mathrm{d}^{24,36-40}$ to get a global picture of the costs of torture for a host country.

\section{Switzerland's migration context}

and its survivors of torture profile

The law of the Asylum Act of June 26, 1998, and modified on July 1, 2013, rules the access to asylum and to the status of refugee, as well as the provisional protection given to those in need. This law defines the refugee as an individual who in his home country or his country of residence is exposed to serious prejudice because of his race, religion, nationality, ethnic, or social group membership. The law makes the distinction between asylum seekers (not yet accepted) and refugees (accepted).
Table I Asylum demands and recognized refugees in Switzerland (2008-2010)

\begin{tabular}{llll}
\hline Period & $\mathbf{2 0 0 8}$ & $\mathbf{2 0 0 9}$ & $\mathbf{2 0 1 0}$ \\
\hline Asylum demands & 16,606 & 16,005 & 15,567 \\
Positive decision & 2,261 & 2,622 & 3,449 \\
$\begin{array}{l}\text { Negative decision } \\
\text { Decision of not considering }\end{array}$ & 4,483 & 5,750 & 6,541 \\
the demand & 3,073 & 7,678 & 9,466 \\
$\begin{array}{l}\text { Elimination of the demand } \\
\text { Provisional admission }\end{array}$ & 2,062 & 1,276 & 1,234 \\
$\begin{array}{l}\text { Recognized refugees } \\
\text { living in the country }\end{array}$ & 2,747 & 4,053 & 4,796 \\
\hline
\end{tabular}

Note: Data from the Federal Office of Migration 2008, 2009, and 2010. ${ }^{24}$

Table 1 shows the situation in Switzerland over the 2008-2010 period. The countries of origin of asylum seekers vary over time depending on the local social and political conditions. For example, in 2008, there were $17.2 \%$ from Eritrea; $12.1 \%$ from Somalia; $8.7 \%$ from Iraq; $7.8 \%$ from Serbia and Kosovo; 7.6\% from Sri Lanka; 5.9\% from Nigeria; 3.1\% from Turkey; $2.9 \%$ from Afghanistan; and 2.4\% from Iran.

In 2001, the situation was quite different: $16 \%$ of asylum seekers from the Federal Republic of Yugoslavia; 9.4\% from Turkey; 6\% from Bosnia-Herzegovina; 5.8\% from Guinea; $4.3 \%$ from Macedonia; and 2.9\% from the Democratic Republic of the Congo. ${ }^{41}$

Roughly $80 \%$ of the survivors of torture are males with a mean age of 35 years; $40 \%$ have a higher education (vocational or university); $70 \%$ have no job; and the proportion of invalids is $10 \%{ }^{42}$ In addition, the proportion of children is around $35 \%{ }^{42}$

\section{Results}

\section{Model applied to case study}

Prevalence of victims of torture

\section{in Switzerland}

Many authors report that - on average - $30 \%$ of refugees in a Western country have been victims of torture in their home country. ${ }^{15,21-23}$ Their estimation of the number of potential victims of torture is based on the total number of refugees in a given host country. Their socioeconomic characteristics are assimilated to the subgroup of refugees, ${ }^{33}$ thus, our estimation is of 24,000 refugees on average and 7,200 potential survivors of torture.

\section{Socioeconomic indicators}

Estimations of living costs, health care costs, costs related to the education of children, and the invalidity ratio were all based on the data of the administrative sources and on data from the specific studies. Details are given in the section "Case study." 
The mean age, average income, handicap ratio, and amount of money to cover basic needs were all considered as key factors to take into account in the cost estimation, as suggested in the literature considering various health problems. $^{28-30}$

\section{Estimation of productivity loss and the economic burden of disease}

The analysis of the various components of the costs related to torture was adopted and allowed the estimation of the direct and indirect costs - such as loss of productivity, costs of health care, and costs related to education.

\section{Case study}

The model was applied to the situation in Switzerland. It was conducted in a three-step sequence.

First, the number of potential victims was determined based on the total average number of refugees in Switzerland over a three-year period from 2008-2010. The number of refugees was established from the data of the Swiss Federal Office for Migration, which examines the request of each asylum seeker and decides to accept him or her as a refugee. ${ }^{33}$

Second, the basic socioeconomic indicators were determined regarding the various costs to be estimated. The daily cost for basic needs was established on the basis of the average daily allowance for each asylum seeker of the federal state to the cantons. Concerning the living costs, we applied the mean daily allowance the Swiss Federal Government allocates to the cantons for each asylum seeker. For example, this amounted to 55.64 Swiss francs (CHF), according to an official report to the Swiss Federal Committee for Migration. ${ }^{43}$

Concerning health care costs, we settled on 2,277 CHF, based on several data sources data from the Swiss Federal Office of Migration which puts forward yearly costs of 2,280 CHF per refugee in $2000 .{ }^{24}$ From a study in the canton of Zurich in 2010 , the estimation was $2,445 \mathrm{CHF}{ }^{40}$ Costs for the education of the children of the survivors of torture were estimated on the basis of what the costs are for schooling a child per year as published by the Swiss Federal Administration as $13,700 \mathrm{CHF}^{24}$

Concerning invalidity, we applied a ratio of $10 \%$ based on the data of some authors who proposed $13 \%{ }^{44}$

Concerning the costs related to nonproductivity (the human capital approach), the amount of healthy productive life-years lost among adult victims of torture was used. The loss of productivity was estimated, taking into account the mean age of victims of torture and the legal age of retirement in Switzerland (65 years for men; 64 for women).
Data from the Federal Office of Migration and the Swiss Red Cross Ambulatory Service for Victims of Torture and Warfare reported that only $30 \%$ of victims of torture are professionally active and the $10 \%$ invalid rate was also taken into account to estimate loss of productivity. $24,39,40$ Also, we considered the costs related to the education and social integration of the children of victims of torture, ie, considering that $35 \%$ of the population of refugees is under 18 , considering also the average number of schooling years, and the yearly costs of schooling in Switzerland.

Third, data concerning these indicators have been applied to the sociodemographic characteristics of survivors of torture in Switzerland. The costs are summarized in Tables 2 and 3. The estimated number of potential survivors of torture (direct victims of torture, eg, proved victims of torture with sequelae, or indirect victims of torture, eg, children of a proved victim of torture) is 7,200 at present in Switzerland; 4,680 of this 7,200 belong to the age group of the active population ( $>20$ and $<65$ years old), with a mean of 35 years of age. Children, either direct victims of torture or indirect ones, amount to 2,520 (Table 2).

The costs related to torture can be split into direct costs and indirect costs (Table 3). Direct costs, such as housing, food, and clothing, represent roughly 130 million CHF per year, whereas health care costs amount to 16 million CHF per year, and the cost related to education of young people amounts to 34 million CHF per year. Indirect costs, namely those costs related to the loss of productivity of direct survivors of torture, have been estimated to one-third of 1 billion CHF per year. This jumps to 10,073,419,200 CHF in loss of productivity if one would consider 30 years of loss per survivor (mean age, 35 years; age of retirement, 65 years).

\section{Discussion}

Prior to any interpretation and utilization of the results of our study, one should keep in mind certain considerations. In any population, there are pathologies that trigger costs for the society. As an example, one might consider the economic costs of brain disorders reported by some authors ${ }^{45}$ in the European region in 2010. The total cost of brain disorders was " $€ 798$ billion, of which direct health care cost $37 \%$, direct nonmedical cost $23 \%$, and indirect cost $40 \%$; average cost per inhabitant was $€ 5,550$ ". ${ }^{45}$

Our study only considers costs related to the formal sector, not taking into account costs that are related to the informal sector; for example, the health care provided to a victim of torture by family members. 
Table 2 Basic indicators for cost analysis of torture in host country (Switzerland)

\begin{tabular}{|c|c|c|c|}
\hline & $\begin{array}{l}\text { Estimated } \\
\text { number and costs }\end{array}$ & $\begin{array}{l}\text { Estimated \% of } \\
\text { torture victims }\end{array}$ & Source \\
\hline I. Population at risk (refugees) & 24,000 & & 24 \\
\hline 2. Potential survivors of torture (direct and indirect) & 7,200 & $30 \%$ of 1 & 21,23 \\
\hline 3. Active population among victims of torture & 4,680 & $65 \%$ of 2 & 24 \\
\hline 4. Invalids & 468 & $10 \%$ of 3 & 38 \\
\hline $\begin{array}{l}\text { 5. In education or training programs population among survivors } \\
\text { of torture (direct and indirect) (young people age }<20 \text { years) }\end{array}$ & 2,520 & $35 \%$ of 2 & 24 \\
\hline 6. Costs for living (housing, food, clothing, etc) per person per year & I8,03I CHF & - & 24 \\
\hline 7. Costs related to health care per person per year & $2,277 \mathrm{CHF}$ & - & 24 \\
\hline $\begin{array}{l}\text { 8. Costs related to education for young people age }<20 \text { years per } \\
\text { person per year }\end{array}$ & $13,700 \mathrm{CHF}$ & - & 43 \\
\hline 9. Mean national income per active person per year & $71,748 \mathrm{CHF}$ & - & 43 \\
\hline 10. Mean age of survivors of torture & 35 years & - & 38 \\
\hline II. Legal country age of retirement & 65 years & - & 36,39 \\
\hline 12. Estimated years of life saved for survivors of torture per person & 30 years & - & 43 \\
\hline
\end{tabular}

Abbreviation: $\mathrm{CHF}$, Swiss franc.

The estimation of the costs related to the torture in a host country with a well-developed social system needs to take into account a series of factors, such as: the access to demographic data related to migrant populations, such as refugees and asylum seekers (Figure 1); economic and social data related to the general population; the access to data related to working conditions, social security, health care organization, and the legal framework regulating social security; and the rights of citizens as well as the situation of asylum seekers and refugees.

Yet the nature of the indicators used calls for some explanation as well as the sources they are based on: the prevalence of the victims of torture among refugees represents the base on which our model is constructed; the number of asylum seekers and accepted refugees is very country dependent; and various studies have shown important fluctuations. For example, in 2010, there were: 15,567 asylum demands in Switzerland; in France, 52,762 demands were made the

Table 3 Estimated yearly costs related to torture in Switzerland

\begin{tabular}{ll}
\hline Nature of costs & $\begin{array}{l}\text { Estimated yearly } \\
\text { costs in Swiss francs }\end{array}$ \\
\hline $\begin{array}{l}\text { Costs for living (housing, food, clothing, etc) } \\
\text { of direct and indirect survivors of torture }\end{array}$ & $129,823,200 \mathrm{CHF}$ \\
$\begin{array}{l}\text { Costs related to health care of direct and } \\
\text { indirect survivors of torture }\end{array}$ & $16,394,400 \mathrm{CHF}$ \\
$\begin{array}{l}\text { Costs related to education for young } \\
\text { people age }<20 \text { years (direct and indirect } \\
\text { survivors of torture) }\end{array}$ & $34,524,000 \mathrm{CHF}$ \\
$\begin{array}{l}\text { Costs related to loss of productivity } \\
\text { of direct survivors of torture }\end{array}$ & $335,780,640 \mathrm{CHF}$ \\
\hline Abbreviation: CHF, Swiss franc. &
\end{tabular}

same year. ${ }^{24,46}$ In Switzerland, the estimated number of accepted refugees residing at a given moment in the country is close to 24,000, as reported by the Swiss Federal Office for Migration..$^{24}$ The prevalence of potential victims of torture among those refugees is estimated at $30 \%$ in Switzerland as reported in various studies, ${ }^{21,22,24,38}$ but the data varies from study to study, country to country, and time period to time period.

Masmas et al, ${ }^{47}$ for example, reported $45 \%$ in Denmark. Quiroga et $\mathrm{al}^{17}$ from Sweden report even higher percentages, for example, 51\% among a cohort of 2,930 refugees who arrived to the country by air. Thus, the $30 \%$ we used in our model is an estimation that might change according to specific situations. This estimation might even be an underestimation. Indeed, the prevalence of victims of torture can vary greatly depending on the country of origin of the survivors as well as the period of time.

The sociodemographic indicators used in our study, such as the age of retirement, the average income, and the percentage of professional activity, are based on data from the Swiss Federal Office for Statistics, the Swiss Forum on Migration Studies, and the Swiss legislation on the age of retirement; ${ }^{24,38,39}$ those indicators might present some variations when new laws are introduced, for example, or if the age structure of the migrant population was to change drastically or if the economy went down. This has not been the case over the studied period. The differences from one host country to another will, of course, impact costs.

The costs related to the schooling of the children of victims of torture are rough estimates, because there is no specific data on the costs of early integration classes, which 
those children go to for a few weeks/months before being integrated into normal classes. One should also keep in mind the high percentage of children of foreign origin who are integrated into special classes with more teaching personnel per child and fewer learning objectives. The numbers have been on the increase since 1980 (4\% in 1980; $8 \%$ in 1996; and $43 \%$ in 2004). ${ }^{48,49}$

Furthermore, torture experiences are difficult to quantify, and the individual responses vary enormously, depending - among many other things - on support from family and friends, on the level of education, and on concrete employment opportunities. These factors, of course, all influence possible costs.

As one can see from these described situations, the developed model for estimating the economic costs of torture in a host country is, therefore, very much country-dependent and in close relation to the legal, social, economic, and humanitarian frameworks of each country. Yet, we consider that our study might be of interest to clinicians, social workers, and politicians in charge of the survivors of torture, even though there are many limits in our approach.

As shown in our case study, the costs related to torture for a host country of the victims of torture could be quite important. Compressing such cost might be possible in some areas, such as health care, through early detection of survivors of torture and through the development of therapy centers that are specialized in the rehabilitation of victims of torture. However, compressing costs related to basic needs (housing, food, clothing) might be more difficult. Indeed, a vast majority of host countries have ratified international protocols and conventions that fix the obligations that states have regarding their citizens, but also migrant populations established on their territory (the Geneva Convention, the International Covenant on Civil and Political Rights, the International Covenant on Economic, Social and Cultural Rights, the Convention on the Rights of the Child, etc), such as ensuring basic needs, but also ensuring the basic education of children or ensuring their access to primary health care.

The loss of productivity of the victims of torture is a major source of indirect costs for a host country. Therefore, professional integration and reorientation of the survivors of torture should be a priority for any host country - all the more that such an approach contributes to the overall well-being of a survivor of torture. ${ }^{39}$

The economic costs of systematic torture are so enormous that politicians and the international community should integrate them in their discussions on international cooperation and development. Indeed, torture should be part of the negotiation when the financing of cooperation projects is considered - not only out of a human rights perspective but also because of those enormous costs. The states that have instituted torture as a way of governing should be accountable - not only for the cost related to the care and the rehabilitation of victims of torture but also for the costs related to the asylum and the chronic nonproductivity of victims of torture.

According to our estimates, in the case of Switzerland, the annual costs related to the rehabilitation of victims of torture correspond to roughly one-half of the budget allocated to cooperation and development and three times to the budget allocated to the promotion of peace and security worldwide. ${ }^{50}$ In a more restrictive health perspective, the costs related to the rehabilitation of victims of torture in

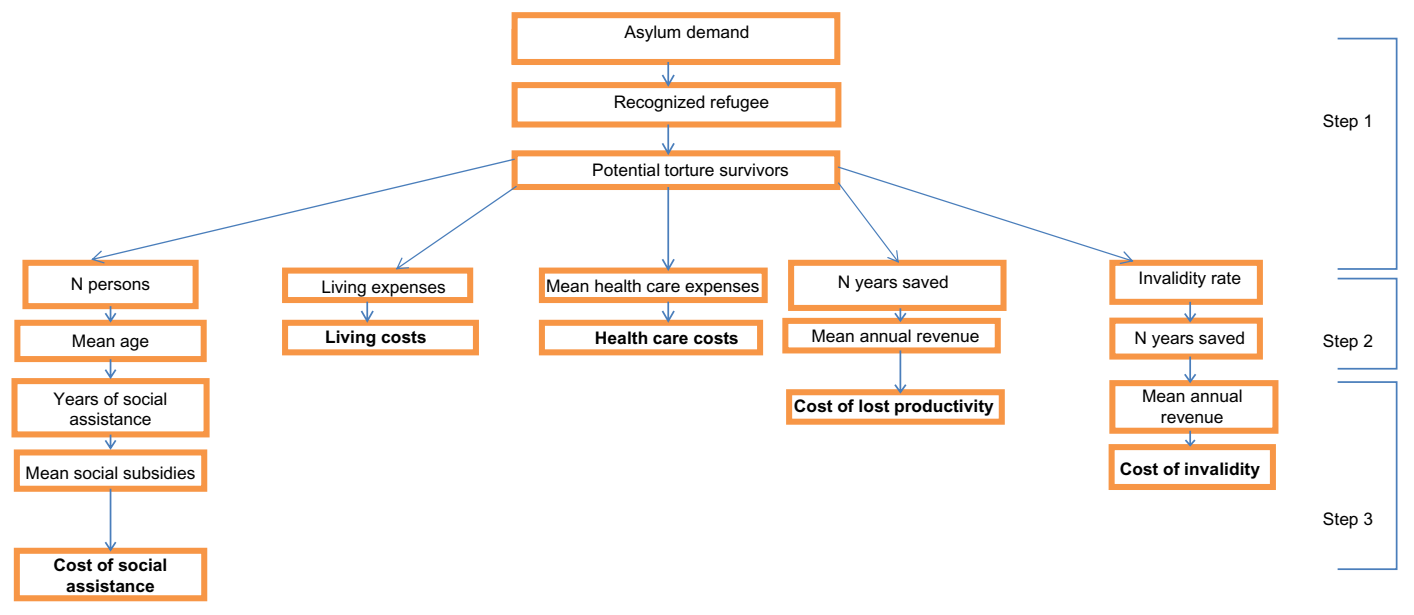

Figure I Socioeconomic costs of torture: model of cost estimation of survivors of torture in a host country. Costs appear in bold text. Abbreviation: $\mathrm{N}$, number. 
Switzerland correspond more or less to ten hospitals of reference for 20 million people in an African country.

In our views, torture has a major negative impact on the peace and the development of states where it is systematically practiced, but torture also is responsible for collateral damage in the host countries of the victims of torture. These host countries could and should consider the states practicing torture as fully accountable for such a situation.

Torture could even represent much higher costs, should intangible costs related to chronic pain be taken into consideration (which we did not consider in our study). Indeed, it is well-known that victims of torture very often suffer from chronic pain related to various psychological and physical sequels. ${ }^{51}$ In the literature, authors report between $63 \%-80 \%$ of victims of torture who suffer from long-lasting chronic pain that needs specific care. ${ }^{52,53}$ One should keep in mind that one single chronic pain patient (all pathologies included) represents yearly costs related to health care of 5,665 CHF (twice as high in the case of elevated depression scores), as reported from Ireland, ${ }^{54}$ or that $61 \%$ of people with chronic pain have trouble holding a job, as reported in a European study. ${ }^{55}$

But it could be argued that taking well-integrated and healthy individuals as a baseline for comparison of costs to the social system of a country is a biased view and artificially raises global social costs of survivors of torture; perhaps it would be more reasonable to consider as a baseline controls with similar life courses except for torture. This is an interesting argument that indeed can be made. We took the option in our case study to compare the survivors of torture to the general population, since data of the Swiss Red Cross shows that survivors of torture were previously rather well-integrated and educated individuals in their home countries. ${ }^{22,38}$

What could help in reducing the costs of torture? Prevention surely could. Indeed, costs could be easily reduced if prevalence and incidence of torture were to come down throughout the world, especially in countries where torture is very common.

Nonetheless, let's consider some limits of our approach. One limiting factor might be the various existing definitions of torture: from straightforward torture to nonhuman treatment, such as psychological manipulation, though some $\mathrm{e}^{44,56}$ - who have worked in extreme situations in former Yugoslavia - have come to the conclusion that both cause much suffering and, therefore, might be considered as similar. Another critical point that might greatly affect the global cost estimations of victims of torture in a host country is the estimation of the number of victims of torture, based on the number of accepted and officially recognized refugees, a number that represents 10\%-20\% of asylum seekers in Switzerland over the past decade ${ }^{33}$ and 1\%-39\% among the European Union member countries in $2007 . .^{52}$

The estimation of health care costs might also be difficult since often health care costs are not specifically identified for legally recognized refugees but rather for asylum seekers, as is the case in Switzerland. ${ }^{32}$ The estimation of the costs related to basic needs, such as housing, clothing, and food, might also heavily be influenced by local factors, as it is the case in Switzerland where important differences between cantons (from 320-768 CHF per person per month) have been reported by the Swiss Federal Commission on Migration. ${ }^{37}$ Furthermore, no estimation of intangible costs - such as the ones related to physical pain or psychological distress - have been considered in our study, though pain and psychological distress are certainly major problems to survivors of torture. ${ }^{52}$

We are aware that the results of our study might be used in different ways. Some might use them to justify restrictive migration policies; this is by no means our position. Others might consider these results as a basis for the development of specific care services for victims of torture as well as a strong argument in favor of the fight against torture, an approach we share.

\section{Conclusion}

It has been argued that the complexity of the practice of torture, the variety of health problems related to torture, the different approaches in taking care of victims of torture, the huge differences in wealth among countries, and the variety of economic problems among host countries are major obstacles to the estimation of costs related to torture.

Our study shows that a rough estimation of such costs is possible with some prerequisite, such as the access to social and economic indicators at the country level.

On a more political level, our study should be considered as a plea to host countries to get more strongly and deeply involved in the prevention and elimination of torture - and not as a possible justification in discouraging and refusing refugee claims.

\section{Acknowledgment}

The authors thank the Swiss Red Cross Ambulatory Service for Victims of Torture and Warfare for its help.

\section{Disclosure}

The authors report no conflicts of interest in this work. 


\section{References}

1. Moisander PA, Edston E. Torture and its sequel-comparison between victims from six countries. Forensic Sci Int. 2003;137(2-3):133-140.

2. Scott RG. The History of Torture Throughout the Ages. Whitefish, Montana: Kessinger Publishing; 2003.

3. Daud A, Skoglund E, Rydelius PA. Children in families of torture victims: transgenerational transmission of parents' traumatic experiences to their children. International Journal of Social Welfare. 2005;14(1):23-32.

4. Einolf CJ. The Fall and Rise of Torture: A Comparative and Historical Analysis. Sociological Theory. 2007;25(2):101-121.

5. un.org [homepage on the Internet]. Convention against Torture and Other Cruel, Inhuman or Degrading Treatment or Punishment, Resolution. United Nations General Assembly; 1984. Available from: http://www. un.org/documents/ga/res/39/a39r046.htm. Accessed March 2, 2013.

6. Green D, Rasmussen A, RosenfeldB. Defining torture: a review of 40 years of health science research. J Traumatic Stress. 2010;23(4):528-531.

7. Amnesty International. Combating Torture: A Manual for Action. London: Amnesty International UK; 2003.

8. Mpinga EK, Zesiger V, Arzel B, Golay M, Chastonay P. De l'épidémiologie à la réhabiltation des victimes des tortures: quels rôles pour les professionnels de santé [The epidemiology of rehabilitation of the victims of torture: roles for health professionals]. Bulletin des Médecins Suisses. 2005;86(18):1086-1089. French.

9. Conrad CR, Moore WH. What Stops the Torture? American Journal of Political Science. 2010;54(2):459-476.

10. Welch M. The re-mergence of torture in political culture: tracking its discourse and genealogy. Capítulo Criminológico: Revista de las Disciplinas del Control Social. 2007;35(4):471-505.

11. Hristova M. Analyse démographique des demandeurs d'asile et des réfugiés au Canada (2000-2010) [Demographic analysis of asylum seekers and refugees in Canada (2000-2010)] [master's thesis]. Montréal: University of Montréal; 2012. French.

12. Fariss CJ, Schnakenberg KE. A Human Rights Network Influences Countries'Torture Policies: Annual Meeting of the American Political Science Association, Toronto, Ontario, Canada, 3-6 September 2009. New York, NY: Cambridge University Press; 2009.

13. Hjorth-Madsen M. The cost of coherence: the case of EU-funding for rehabilitation of torture victims. Torture. 2005;15(1):51-58.

14. Rodley N. Securing, redress and overcoming immunity-some reflections. The International Journal of Human Rights. 2012;16(5):691-693.

15. van Boven T. The need to repair. The International Journal of Human Rights. 2012;16(5):694-697.

16. Echeverria G. Do victims of torture and other serious human rights violations have an enforceable right to reparation? The International Journal of Human Rights. 2012;16(5):698-716.

17. Quiroga J, Janranson JM. Politically motivated torture and its survivors: a desk study review of the literature. Torture. 2005;16(2-3):1-112.

18. Yakovlev P. The economics of torture. In: Coyne CJ, Mathers RL, editors. The Handbook on the Political Economy of War. Northampton, MA: Edward Elgar Publishing; 2011:109-125.

19. Maswere WD, Wamono F. Estimating the Socio Economic Effects of torture in Uganda. African Centre for treatment and Rehabilitation of Torture Victims, Kampala, 2013. Available from: http://www.actvuganda. org/sites/default/files/Estimating\%20the\%20Socio-Economic\%20 Effects\%20of\%20Torture\%20in\%20Uganda_ACTV-March\%202013. pdf. Accessed June 13, 2013.

20. van der Veer G. Counselling and Therapy with Refugees and Victims of Trauma: Psychological Problems of Victims of War, Torture and Repression (Wiley Series in Psychotherapy and Counselling). New York: John Wiley and Sons; 1992.

21. Wicker HR. Die Sprache Extremer Gewalt: Studie Zur Situation von gefolterten Flüchtlingen in der Schweiz und zur Therapie von Folterfolgen [The Language of Extreme Violence: Study on the situation of tortured refugees in Switzerland and on the treatment of torture consequences]. Bern: Institute of Ethnology, University of Bern; 1993. German.
22. Frey C. Le traitement des Victimes des Tortures et des Victimes de Guerre en exil: Premières Expériences du Centre de Thérapie CRS [The treatment of victims of torture and victims of warfare in exile: first experiences of the Center of Therapy CRS]. Bulletin des Médecins Suisse. 1998:S52-S58. French.

23. Baker R. Psychosocial consequences for tortured refugees seeking asylum and refugee status in Europe. In: Basoglu M, editor. Torture and its Consequences: Current Treatment Approaches. Cambridge: Cambridge University Press; 2003:83-106.

24. OFM, Office Fédéral des migrations. Statistique du domaine de l'asile. Rapports annuels. Available from: http://www.bfm.admin.ch/ content/bfm/fr/home/dokumentation/zahlen_und_fakten/asylstatistik/ jahresstatistiken.html. Accessed December 12, 2012.

25. Collins DJ, Lapsley HM. The Costs of Tobacco, Alcohol and Illicit Drugs Abuses in Australian Society. Canberra: Commonweatlh of Australia; 2008. Available from: http://www.health.gov.au/internet/drugstrategy/ publishing.nsf/Content/34F55AF632F67B70CA2573F60005D42B/\$ File/mono64.pdf. Accessed April 13, 2013.

26. American Diabetes Association. Economic costs of diabetes in the US in 2007. Diabetes Care. 2008;31(3):596-615.

27. Wimo A, Winblad B, Jönsson L. The worldwide societal costs of dementia: Estimates for 2009. Alzheimers Dement. 2010;6(2):98-103.

28. Solomon SD, Davidson JR. Trauma: prevalence, impairment, service use, and cost. J Clin Psychiatry. 1997;58 Suppl 9:5-11.

29. Lebrun T, Selke B. L'évaluation du coût social de l'alcoolisme en France [Evaluation of the social cost of alcoholism in France]. Actualité et Dossier en Santé Publique. 2004;3(46):77-80. French.

30. Patra J, Popova S, Rehm J, Bondy S, Flint R, Giesbrecht N. Economic cost of chronic disease in Canada 1995-2003. Ontario: Public Health Agency; 2007. Available from: http://www.cdpac.ca/media. php?mid=260. Accessed May 5, 2013.

31. Landefeld JS, Seskin EP. The economic value of life: linking theory to practice. Am J Public Health. 1982;72(6):555-566.

32. Hutubessy RC, van Tulder MW, Vondeling H, Bouter LM. Indirect costs of back pain in the Netherlands: a comparison of the human capital method with the friction cost method. Pain. 1999;80(1-2):201-207.

33. Goeree R, O'Brien BJ, Blackhouse G, Agro K, Goering P. The valuation of productivity costs due to premature mortality: a comparison of the human-capital and friction-cost methods for schizophrenia. Can $J$ Psychiatry. 1999;44(5):455-463.

34. Hogan P, Dall T, Nikolov P. American Diabetes Association. Economic costs of diabetes in the US in 2002. Diabetes Care. 2003;26(3): 917-932.

35. Shlens J. A Tutorial on Principal Component Analysis. Derivation, Discussion and Singular Value Decomposition. Systems Neurobiology Laboratory: University of California at San Diego; 2003. Available from: http://www.cs.princeton.edu/picasso/mats/PCA-Tutorial-Intuition_ jp.pdf. Accessed March 19, 2012.

36. Piguet E, Mistelli R. L'intégration des requérants d'asile et des refugiés sur le marché du travail [Integration of applicants for asylum and refugees into the labor market]. Neuchâtel: Forum Suisse pour l'etude des migrations; 1996. French.

37. Wichmann N, Hermann M, D'Amato G, et al. Les marges de manœuvre au sein du fédéralisme: la politique de migration dans les cantons [Room for maneuver in the heart of federalism: canton migration policy]. Zurich: Commission fédérale pour les questions de migration CFM; 2011. Available from: https://www.ekm.admin.ch/content/dam/data/ekm/dokumentation/ materialien/mat_foederalismus_f.pdf. Accessed April 15, 2013.

38. Croix-Rouge Suisse, Service Ambulatoire pour les Victimes de Tortures et de Guerre. Rapport Annuel 2011 [Annual Report 2011]. Berne: Croix-Rouge Suiss; 2012. French.

39. Gerber AC. L'intégration professionnelle des réfugiés en Suisse: situation en 2000 [Professional integration of refugees in Switzerland] [master's thesis]. Geneva: Université de Genève; 2008.

40. Maier T, Schmidt M, Mueller J. Mental health and health care utilization in adult asylum seekers. Swiss Med Wkly. 2010;140:w13110. 
41. Fibbi R. Politique d'asile et questions migratoires [Asylum policy and migration issues]. Annuaire Suisse de Politique de Développement. 2008;27(1):197-217.

42. Croix-Rouge Suisse, Service Ambulatoire pour les Victimes de Tortures et de Guerre. Statistiques 2011 [Statistics 2011]. Berne: Croix-Rouge Suiss; 2012. French.

43. OFS Office fédéral de la statistique. Annuaire statistique de la Suisse [Swiss Annual Statistics]. Berne: Hans Huber Verlag; 2009. Available from: http://www.bfs.admin.ch/bfs/portal/fr/index/dienstleistungen/ publikationen_statistik/statistische_jahrbuecher/stat_jahrbuch_der. html. Accessed December 20, 2012.

44. Špiric Z, Kneževic G. The socio-demographic and psychiatric profiles of clients in the centre for rehabilitation of torture victims- IAN Belgrade, In: Špiric Z, Kneževic G, Jovic V, Opacic G, editors. Torture in War: Consequences and Rehabilitation of Victims - Yugoslav Experience. Belgrade, Serbia: International Aid Network; 2004:121-152.

45. Olesen J, Gustavsson A, Svensson M, Wittchen HU, Jönsson B; CDBE2010 study group; European Brain Council. The economic cost of brain disorders in Europe. Eur J Neurol. 2012;19(1):152-162.

46. OFPRA Office français de protection des réfugiés et apatrides. Rapport d'activité 2011 [Activity report 2011]. Available from: http://www.ofpra. gouv.fr/documents/OfpraRA2011.pdf. Accessed April 13, 2013.

47. Masmas TN, Møller E, Buhmannr C, et al. Asylum seekers in Denmark-a study of health status and grade of traumatization of newly arrived asylum seekers. Torture. 2008;18(2):77-86.

48. OFS Office fédéral de la statistique. Intégration: une histoire d'échecs? Les enfants et les adolescents étrangers face au système Suisse de formation [Integration: a failure story? Children and teenagers confronted by the Swiss education system]. Berne: Office fédéral de la statistique; 1997. French.
49. OFM, Office fédéral des migrations. Problèmes d'intégration des ressortissants étrangers en Suisse [Integration problems of foreigners in Switzerland]. Berne: Office fédéral des migrations; 2006. Available from: http:/www.ejpd.admin.ch/content/dam/data/kriminalitaet/ jugendgewalt/ber-integration-bfm-f.pdf. Accessed June 2, 2013.

50. Swiss Agency for Development and Cooperation SDC. Annual Report 2011. Berne: Swiss Agency for Development and Cooperation; 2011. Available from: http://www.sdc.admin.ch/en/Home/Documentation/ Publications/Annualreports/Annual_reports_archive. Accessed December 12, 2012.

51. Carinci AJ, Mehta P, Christo PJ. Chronic pain in torture victims. Curr Pain Headache Rep. 2010;14(2):73-79.

52. Thomsen AB, Eriksen J, Smidt-Nielsen K. Chronic pain in torture survivors. Forensic Sci Int. 2000;108(3):155-163.

53. Williams AC, Peña CR, Rice AS. Persistent pain in survivors of torture: a cohort study. J Pain Symptom Management. 2010;40(5):715-722.

54. Raftery MN, Ryan P, Normand C, Murphy AW, de la Harpe D, McGuire BE. The economic cost of chronic noncancer pain in Ireland: results from the PRIME study part 2. J Pain. 2012;13(2):139-145.

55. Breivik H, Collett B, Ventafridda V, Cohen R, Gallacher D. Survey of chronic pain in Europe: prevalence, impact on daily life, and treatment. Eur J Pain. 2006;10(4):287-333.

56. Başoğlu M, Livanou M, Crnobarić C. Torture vs other cruel, inhuman, and degrading treatment: is the distinction real or apparent. Arch Gen Psychiatry. 2007;64(3):277-285.
ClinicoEconomics and Outcomes Research

\section{Publish your work in this journal}

ClinicoEconomics \& Outcomes Research is an international, peerreviewed open-access journal focusing on Health Technology Assessment, Pharmacoeconomics and Outcomes Research in the areas of diagnosis, medical devices, and clinical, surgical and pharmacological intervention. The economic impact of health policy and health systems

\section{Dovepress}

organization also constitute important areas of coverage. The manuscript management system is completely online and includes a very quick and fair peer-review system, which is all easy to use. Visit http://www.dovepress.com/testimonials.php to read real quotes from published authors. 